\title{
MONITORING PERUBAHAN POLA ALUR SUNGAI MENGGUNAKAN CITRA SATELIT RESOLUSI SPASIAL MENENGAH BERBASIS SPECTRAL CLASSIFICATION
}

\author{
Agung Kurniawan ${ }^{1}$ \\ ${ }^{1}$ Sistem Informasi Geografis, Departemen Teknologi Kebumian, \\ Sekolah Vokasi, Universitas Gadjah Mada, Indonesia \\ Email: 1agung.kurniawan.16@mail.ugm.ac.id
}

\begin{abstract}
ABSTRAK
The development of remote sensing technology allows humans to acquire and process data remotely and temporally. Changes in the flow of the Progo river from the last few years are significant, this can be caused by natural factors and human factors. The influence of the intensity of flow and the level of sedimentation in the Progo river causes a massive flow pattern change in the Progo river body. The data used in this research is Medium Spatial Resolution Satellite Imagery, Landsat 5 satellite imagery acquired in 1995 and Landsat 8 acquired in 2017. Monitoring of changes in river flow pattern is generally done by using the method of terrestrial or conventional measurement, which takes a long time, for that the use of methods and remote sensing data can be used to save time. The method used is multispectral classification approach with maximum likelihood algorithm. The results of extraction using digital classification method (maximum likelihood) resulted in the appearance of flow pattern quickly and representative, so this method is suitable for the purpose of rapid detection of changes in flow pattern. The results obtained from the extraction of the Progo river flow pattern show an intricate river flow pattern with many river rubbers on the image appearance of 1995, whereas in the image extraction results in 2017 the river banks and turns do not look dominant, it shows that erosion and sedimentation activities continue to occur massively.
\end{abstract}

Keywords: Multispectral Classification, River Flow Patterns, Medium Spatial Resolution Satellite Imagery.

\section{PENDAHULUAN}

Sungai Progo merupakan salah satu dari sekian banyak sungai yang melintasi Provinsi Daerah Istimewa Yogyakarta. Sungai Progo berhulu pada beberapa gunung, yaitu Gunung Sindoro, Gunung Merapi, Gunung Menoreh, Gunung Merbabu dan Gunung Sumbing. Sungai Progo bermuara di pesisir selatan Pulau Jawa pada Pantai Trisik. Panjang sungai utama membentang sejauh $\pm 138 \mathrm{~km}$, dengan luas DAS $2380 \mathrm{~km}^{2}$. Morfologi Sungai Progo sangat beragam seiring dengan perilaku serta aktivitas dari gunung-gunung api yang mengelilingi Sungai Progo (Mananoma et al., 2003). Perubahan morfologi pada sungai dipengaruhi berbagai faktor, baik secara alamiah maupun karena aktivitas manusia. Faktor alamiah yang secara masif mempengaruhi perubahan morfologi pada sungai yaitu, kondisi aliran, kondisi lingkungan dan proses angkutan sedimen, sedangkan faktor manusia yang berperan adalah 
perilaku manusia terhadap pemanfaatan wilayah pematang sungai (Mananoma et al, 2006). Proses morfologi yang masif pada aliran sungai dapat memicu terjadinya kenaikan puncak hidrograf aliran yang terdapat pada suatu sistem alur yang disebabkan oleh pengelolaan lahan yang cenderung mengurangi nilai tahanan terhadap aliran, maupun peningkatan nilai koefisien pengaliran. Kenaikan puncak hidrograf aliran dapat menimbulkan luapan yang mengakibatkan daerah sekitar sungai menjadi tergenang (Jayadi R et al., 2003). Perubahan terdapat pola alur sungai merupakan suatu yang pasti hal ini dapat dilihat melalui Gambar 1 yang menunjukkan perubahan yang terjadi pada pola alur sungai berdasarkan umur sungai.

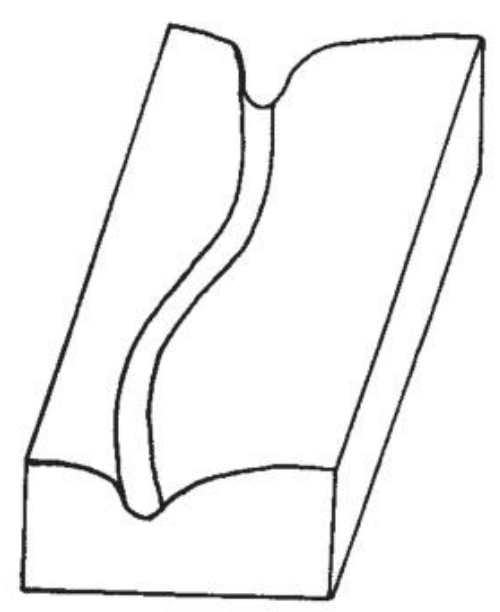

Youth

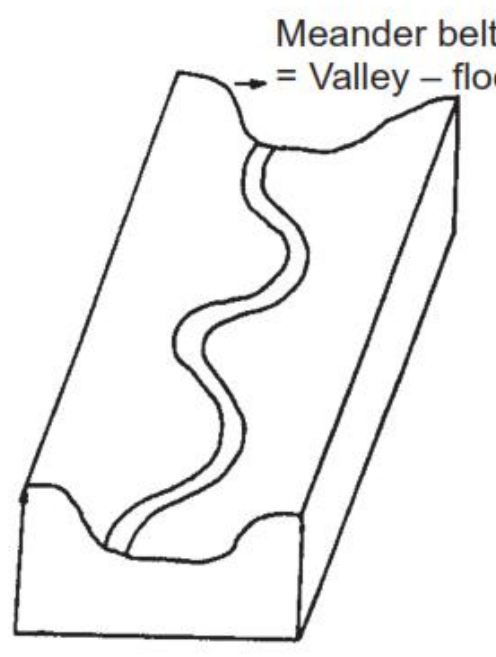

Mature

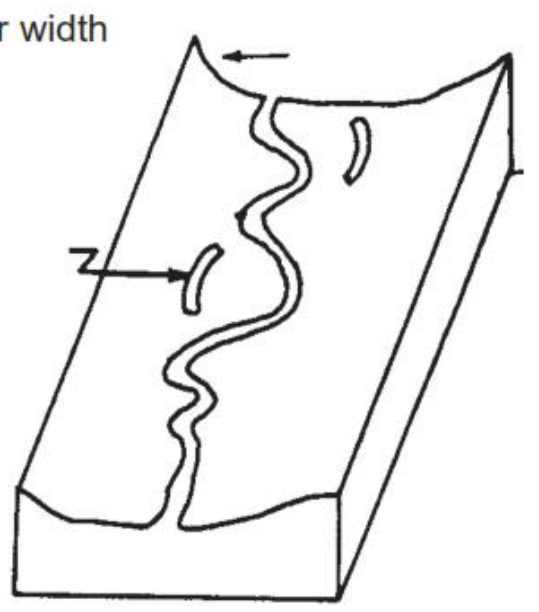

Old

Gambar 1. Bentuk sungai berdasarkan usia (Garde, 2006)

Pengaruh besarnya intensitas arus aliran dan besarnya tingkat sedimentasi pada Sungai Progo menyebabkan perubahan pola aliran secara masif pada tubuh aliran Sungai Progo. Fluktuasi dari aliran debit air yang tinggi menyebabkan perbedaan intensitas tingkat sedimen yang terangkut. Sedimen di Sungai Progo berasal dari beberapa anak sungai terutama sungai yang berhulu di gunung Merapi. Mekanisme angkutan sedimen pada badan sungai akan disertai dengan proses erosi dan sedimentasi yang menyebabkan pola alur pada badan sungai berubah (lihat Gambar 2). Sebagai hasilnya dasar sungai akan mengalami degradasi maupun agradasi yang cukup signifikan (Mananoma et al, 2003). 


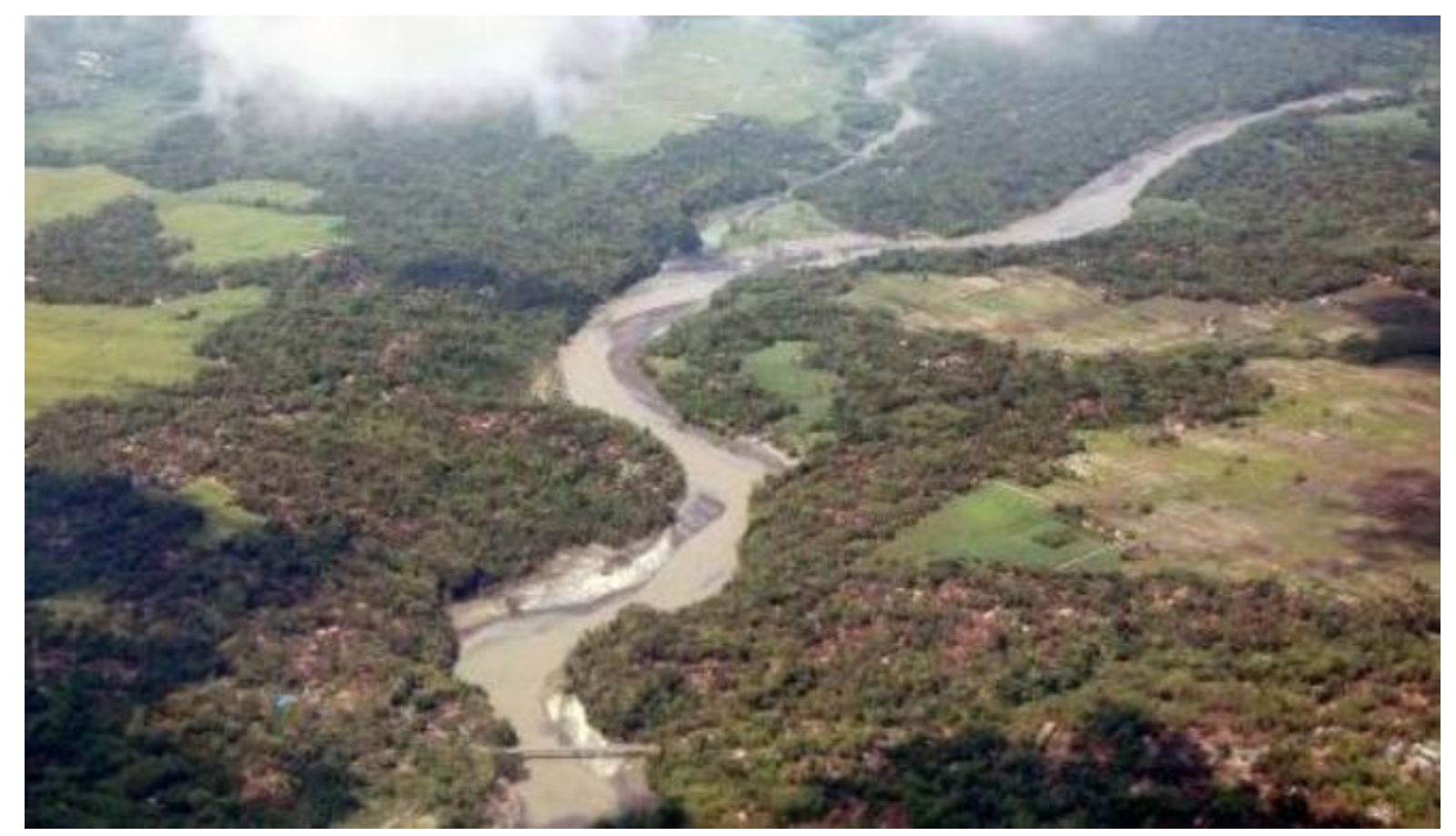

Gambar 2. Kenampakan Sungai Progo membawa material erupsi vulkanik1

Monitoring terhadap perubahan pola alur sungai pada umumnya dilakukan dengan menggunakan metode pengukuran terestris atau konvensional, dengan membutuhkan waktu yang lama, untuk itu penggunaan metode dan data penginderaan jauh dapat dimanfaatkan untuk menghemat waktu. Metode yang digunakan untuk memonitor perubahan pola alur sungai menggunakan data penginderaan jauh ini menggunakan metode pengolahan citra digital spectral based classification.

\section{MATERI DAN METODE PENELITIAN}

\section{Wilayah Kajian}

Penelitian yang dilakukan mencakup bagian Sungai Progo bagian tengah hingga ke hilir. Wilayah yang tercakup dalam kajian ini meliputi Kecamatan Lendah bagian barat, Kecamatan Srandakan bagian utara dan Kecamatan Galur bagian barat. Ketiga wilayah yang termasuk dalam wilayah kajian tersebut secara administratif merupakan bagian dari wilayah administratif Kabupaten Kulon Progo dan Kabupaten Bantul (Gambar 3).

\footnotetext{
${ }^{1}$ Sumber : http://www.viva.co.id/berita/nasional/292726-belerang-merapi-ancam-200-hektar-kolam-ikan
} 


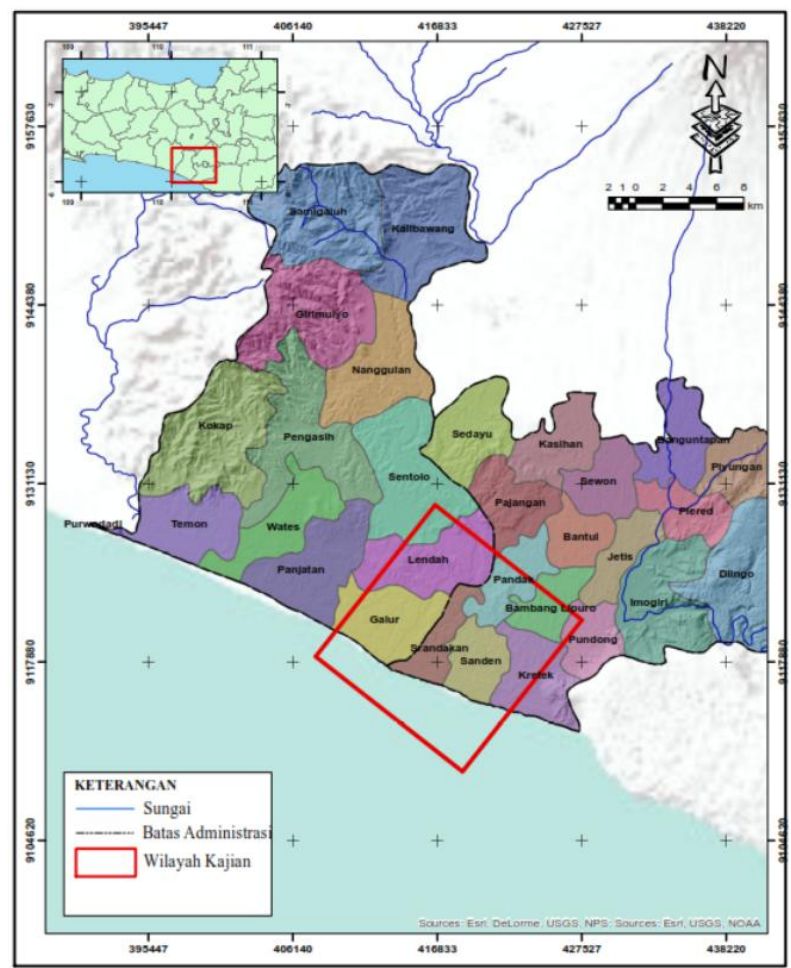

Gambar 3. Wilayah Kajian

Pada penelitian ini menggunakan citra satelit resolusi menengah Landsat 5 dan Landsat 8 level 1. Citra satelit Landsat 8 memiliki resolusi spasial 30 meter untuk saluran multispektral dan 15 meter untuk saluran pankromatik, dengan jumlah saluran spektral berjumlah 11 saluran. Landsat 5 sendiri memiliki resolusi spasial 30 meter untuk saluran multispektral dan 120 meter untuk saluran termal (Gambar 4).

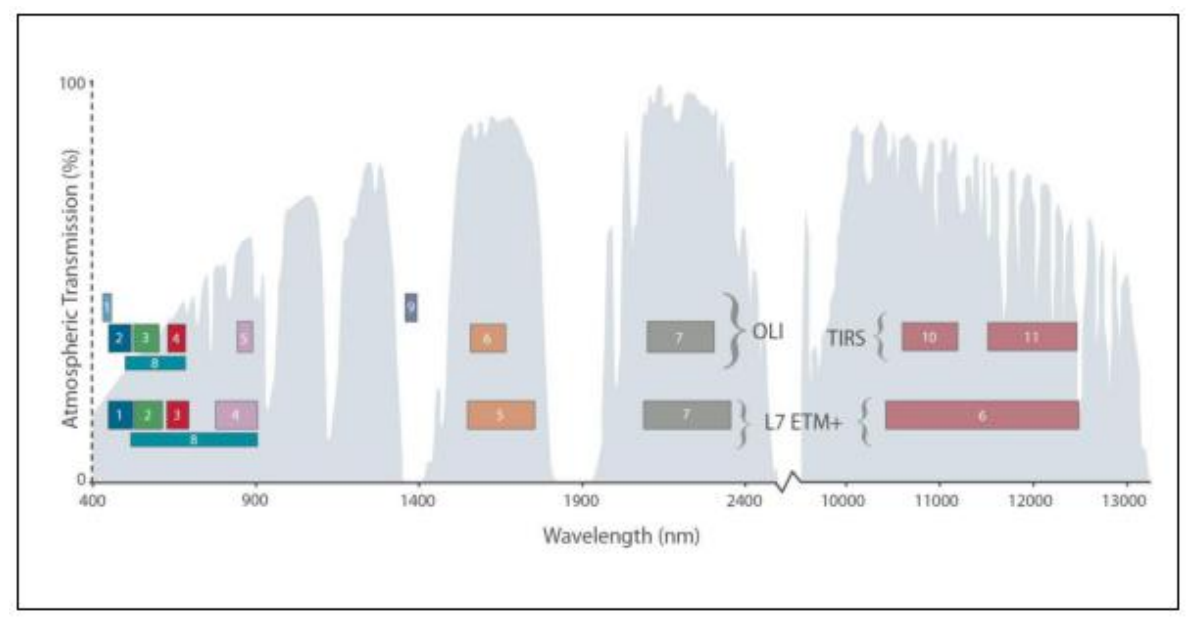

Gambar 4. Perbandingan jumlah saluran spectral Landsat 8 dengan Landsat 7 ETM+ (Landsat 8 Data User Handbook)

Data produk level 1, memiliki arti bahwa citra tersebut belum dilakukan koreksi radiometrik, akan tetapi sudah secara geometrik sistematik, dimana masukan yang digunakan untuk melakukan sinkronisasi sensor menggunakan GCP dan DEMs yang menghasilkan 
produk yang sudah dikoreksi secara geometri dan bebas dari distorsi yang terkait dengan sensor (seperti efek sudut pandang), pada satelit (penyimpangan attitude dari nominal) dan pada bumi (rotasi, kelengkungan, dan relief). Citra Landsat dapat diunduh dengan menggunakan sistem path dan row, hal tersebut dapat dijelaskan oleh Gambar 5.
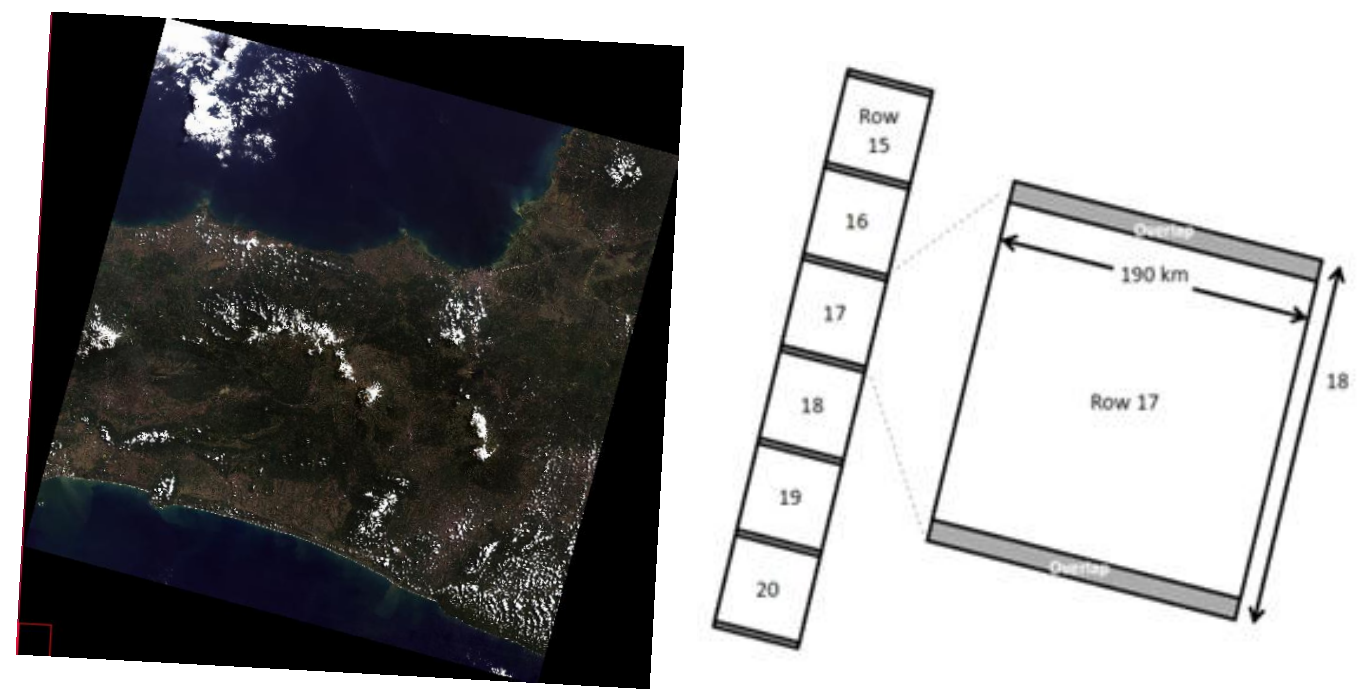

Gambar 5. Citra satelit Landsat 8 true color (kiri) Level 1 Product Ground Swath and Scene Size (Kanan)

Citra juga dilakukan koreksi secara radiometri untuk menghilangkan perbedaan relatif detektor, dan beberapa kesalahan nilai piksel. Rumus algoritma koreksi radiometri antara citra Landsat 5 dengan Landsat 8 memiliki perbedaan, yaitu :

Konversi Radian Landsat 5 :

$$
\begin{gathered}
\mathrm{L} \lambda=\text { Grescale } * \mathrm{QCAL}+\text { Brescale } \\
\text { yang juga dinyatakan sebagai: } \\
\mathrm{L} \lambda=((\mathrm{LMAX} \lambda-\mathrm{LMIN} \lambda) /(\mathrm{QCALMAX}-\mathrm{QCALMIN})) *(\mathrm{QCAL}-\mathrm{QCALMIN})+\mathrm{LMIN} \lambda
\end{gathered}
$$

Dimana: $\quad L \lambda \quad$ : Spectral Radiance at the sensor's aperture in watts/(meter squared * ster * $\mu \mathrm{m})$

Grescale : Rescaled gain (the data product "gain" contained in the Level 1 product header or ancillary data record) in watts/(meter squared * ster * $\mu \mathrm{m}) / D N$

Brescale : Rescaled bias (the data product "offset" contained in the Level 1 product header or ancillary data record) in watts/(meter squared * ster QCAL : the quantized calibrated pixel value in $D N$

LMINג : the spectral radiance that is scaled to QCALMIN in watts/(meter squared $*$ ster * $\mu m$ ) 


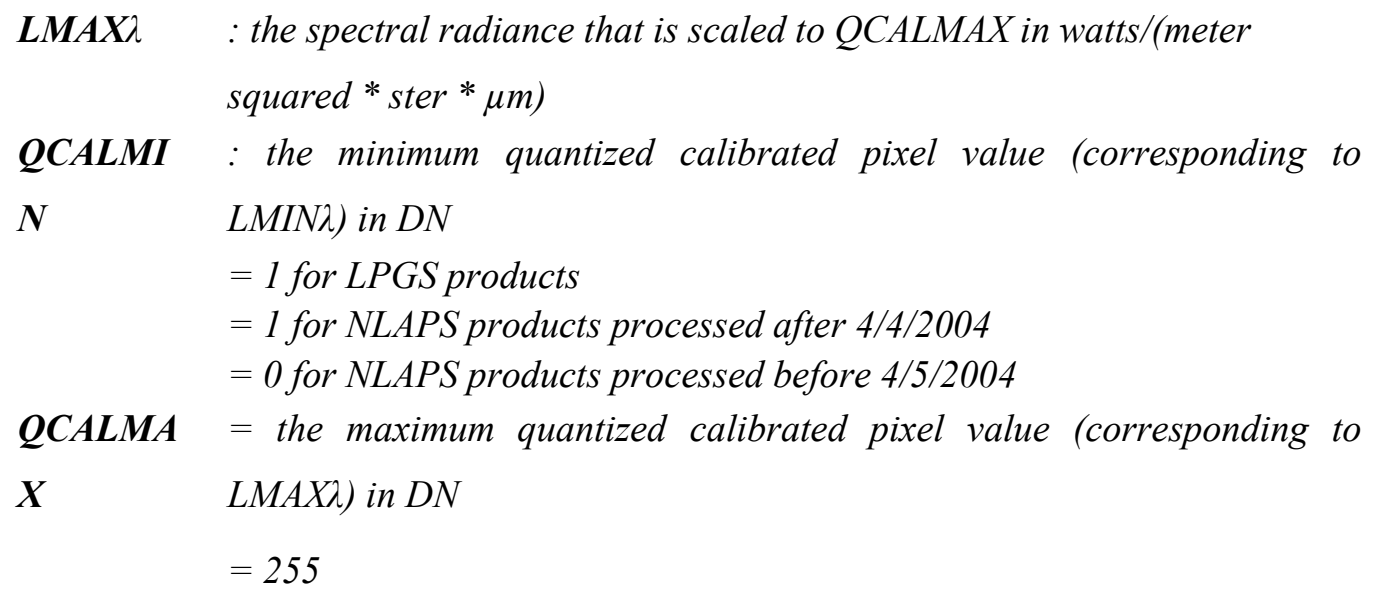

Konversi Spektral Radian Landsat 8 sensor OLI \& TIRS :

$$
\mathrm{L} \lambda=\mathrm{ML} * \mathrm{Qcal}_{\mathrm{c}}+\mathrm{AL}
$$

Dimana :

$$
\begin{array}{ll}
L \lambda & \text { :Spectral radiance }\left(W /\left(m^{2} * s r * \mu m\right)\right) \\
M L & \text { :Radiance multiplicative scaling factor for the band } \\
& \text { (RADIANCE_MULT_BAND_n from the metadata) } \\
A L & : \text { Radiance additive scaling factor for the band } \\
& \text { (RADIANCE_ADD_BAND_n from the metadata). } \\
\text { Qcal } & : \text { L1 pixel value in } \bar{D} N
\end{array}
$$

Konversi Pada Pancaran Spektral :

$$
\rho \lambda^{\prime}=\mathrm{M}_{\rho} * \mathrm{Q}_{\mathrm{cal}}+\mathrm{A}_{\rho}
$$

Dimana :

$$
\begin{aligned}
& \rho \lambda^{\prime} \quad: \text { TOA Planetary Spectral Reflectance, without correction for } \\
& \text { solar angle. (Unitless) } \\
& M_{\rho} \quad \text { : Reflectance multiplicative scaling factor for the band } \\
& \text { (REFLECTANCEW_MULT_BAND_n from the metadata). } \\
& \text { A } \quad \text { : Reflectance additive scaling factor for the band } \\
& \text { (REFLECTANCE_ADD_BAND_Nfrom the metadata). } \\
& \text { Qcal :L1 pixel value in } D N
\end{aligned}
$$

Persamaan tersebut diperoleh dari Landsat 8 Data User Hand Book (United States Geological Survey, 2016). Dari data penginderaan jauh berupa citra satelit resolusi menengah Landsat 5 dan 8 , dapat diidentifikasi perubahan pola alurnya dengan melakukan klasifikasi pada kelas tutupan lahan. klasifikasi dimaksudkan untuk menurunkan data tematik berupa klasifikasi tutupan lahan bersifat raster dan dikonversi menjadi vektor. Algoritma yang digunakan adalah: 


\section{Minimum Distance to Mean (Jarak Minimum Terhadap Rerata)}

Menurut Danoedoro (2012), sistem algoritma minimum distance to mean memberi tiap objek yang sama akan memiliki nilai ganda, pada saluran $1,2,3, \ldots, n$. Setiap piksel dapat di plot pada ruang spectral dan diukur jarak spectralnya terhadap piksel acuan, dengan persamaan :

$$
\text { Jarak }=\sqrt{ }\left(B V_{i j k}-\mu_{c k}\right)^{2}+\left(B V_{i j k}-\mu_{c l}\right)^{2}
$$

$\mathrm{BV}_{\mathrm{ijk}}$ dan $\mathrm{BV}_{\mathrm{ijl}}$ adalah posisi koordinat piksel yang tidak diketahui pada saluran $\mathrm{k}$ dan saluran 1 , sementara $\mu_{\mathrm{ck}}$ dan $\mu_{\mathrm{cl}}$ adalah nilai rerata vektor piksel kelas c di saluran $\mathrm{k}$ dan 1 . Apabila lebih dari dua saluran digunakan sebagai masukan maka rumusnya menjadi :

$$
\left.\operatorname{Jarak}=\sqrt{\sum_{k=1}^{n}(B V i j k}-\mu \mathrm{ck}\right) 2
$$

Dimana $\mathrm{BV}_{\mathrm{ijk}}$ adalah vektor piksel pada saluran $k$ dan $\mu_{\mathrm{ck}}$ adalah nilai rerata vektor piksel kelas $c$ di saluran $k$.

\section{Algoritma maximum - likelihood (Kemungkinan Maksimum)}

Menurut Lillesand, et al. (2004) klasifikasi multispektral dengan algoritma Maximum Likelihood secara kuantitatif mengevaluasi varian dan kovarian dari pola respon spektral saat melakukan klasifikasi pada nilai piksel yang belum diketahui. Asumsi ini biasanya masuk akal untuk respon spektral umum yang terdistribusi. Dengan asumsi ini, distribusi sebuah kategori. Pola respon dapat digambarkan secara lengkap oleh vektor rata-rata dan matriks kovarian. Dengan parameter tersebut, dapat dihitung probabilitas statistik dari nilai piksel tertentu menjadi anggota kelas tutupan lahan tertentu. 


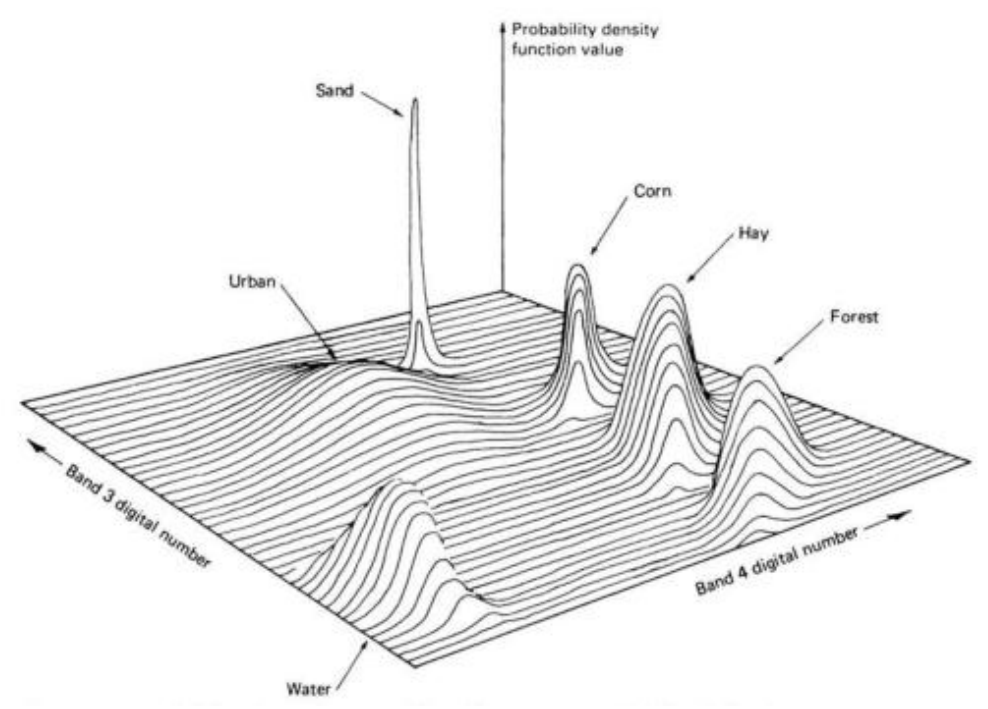

Gambar 6. Fungsi kepadatan probabilitas yang didefinisikan oleh klasifikasi Maximum Likelihood

Sumber : Lillesand and Kiefer, 2004

Gambar 6 menunjukkan nilai probabilitas yang diplot dalam grafik tiga dimensi. Sumbu vertikal dikaitkan dengan probabilitas nilai piksel menjadi anggota salah satu kelas. Permukaan berbentuk lonceng yang disebut disebut fungsi kepadatan probabilitas, dan ada satu fungsi untuk masing-masing kategori spektral.

\section{Metode Penelitian}

Penelitian ini menggunakan Metode Penelitian Deskriptif, dengan menekankan pada penelitian studi komparatif, dimana metode ini memiliki pengertian sebagai suatu jenis penelitian deskriptif yang bertujuan untuk mencari jawaban secara fundamental terkait dengan suatu sebab dan akibat. Penelitian dengan menggunakan metode komparatif bersifat ex post facto, dimana data yang dikumpulkan adalah data setelah kejadian tersebut berlangsung, kemudian melakukan interpretasi terhadap akibat dari suatu fenomena dan menguji hubungan sebab akibat dari data yang telah dikumpulkan. Penelitian ini mengkomparasikan antara kenampakan Sungai Progo pada citra satelit tahun 1995 dan 2017.

\section{HASIL DAN PEMBAHASAN}

Kenampakan citra Landsat 5 tahun 1995 sebelum dilakukan klasifikasi digital baik klasifikasi berbasis objek maupun klasifikasi berbasis spektral, menunjukkan visualisasi tentang pola alur Sungai Progo dengan masih terdapat banyak Gosong Sungai yang terdapat pada bagian hilir di wilayah kajian sebagian Sungai Progo. 


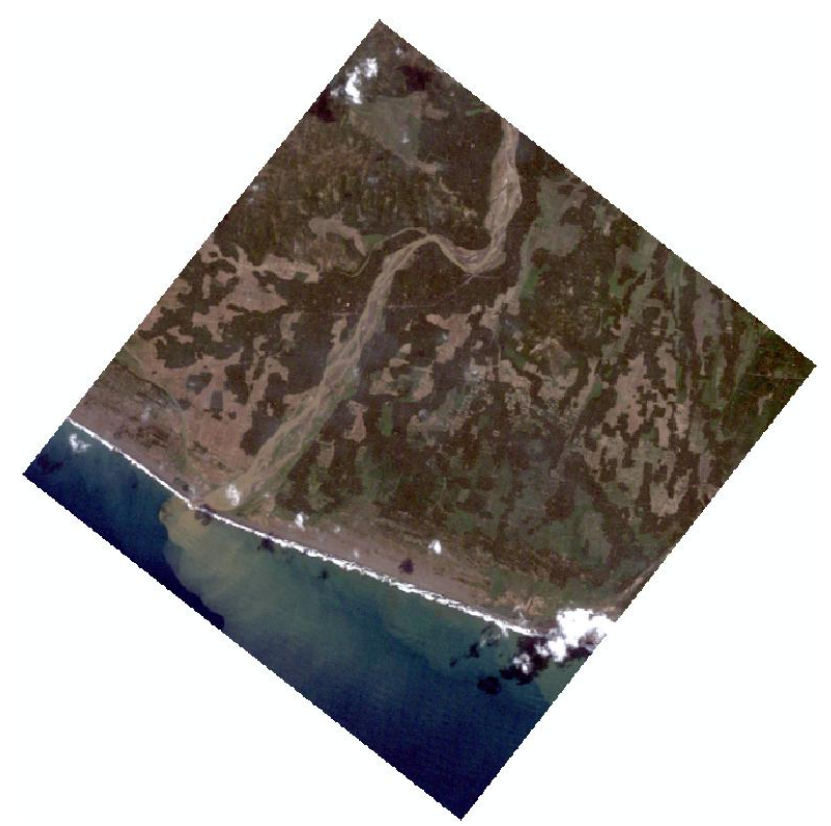

Gambar 7. Kenampakan visual Sungai Progo pada citra satelit Landsat 5 tahun 1995

Citra tersebut di akuisisi pada tanggal 22 Mei 1995 (Gambar 7). Kenampakan visual lain yang nampak pada citra adalah kenampakan air sungai yang pekat, hal ini dapat disebabkan banyaknya sedimentasi yang terbawa oleh aliran air sungai. Citra tersebut memiliki resolusi spasial 30 meter, dengan sensor yang mencakup sensor Visible, Infrared, Pankromatik, dan Thermal.

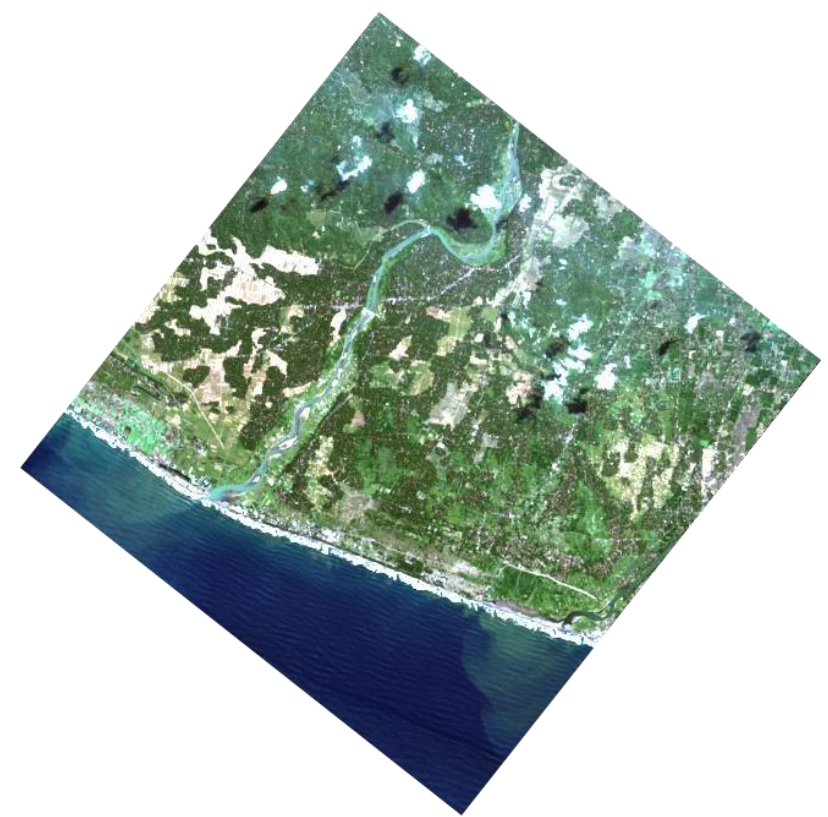

Gambar 8. Kenampakan visual Sungai Progo pada citra satelit Landsat 8 tahun 2017 
Citra Landsat 8 tahun 2017 yang diakuisisi pada 18 Mei 2017 (Gambar 8), memperlihatkan kenampakan bagian hilir Sungai Progo terlihat lebih kecil dalam hal luasan penampang sungai. Interpretasi secara visual menunjukkan adanya perubahan pada pola alur dan badan sungai, akan tetapi tidak secara spesifik. Pola alur Sungai Progo menjadi lebih rumit dengan memiliki banyak lengkungan sungai jika dibandingkan kenampakan Sungai Progo pada citra tahun 1995. Secara interpretasi visual terlihat hilangnya gosong sungai yang sebelumnya ada pada citra Landsat 5 tahun 1995, telah menjadi satu dengan dataran banjir, sehingga nampak alur sungai hanya terdapat satu alur sungai tanpa terbagi dengan gosong sungai.

Monitoring ataupun pemantauan terhadap pola alur Sungai Progo merupakan suatu kegiatan berkelanjutan dalam hal pemantauan, yang pada penelitian ini menggunakan bantuan teknologi penginderaan jauh (citra satelit resolusi menengah) untuk memantau perubahan pola alur Sungai Progo dengan cepat dan efektif. Metode yang digunakan adalah spectral based classification, dimana spectral based classification menggunakan algoritma klasifikasi bebasis nilai spektral piksel pada citra. Pendekatan algoritma yang digunakan adalah maximum-likelihood yang diolah dari citra tahun 1995 dan 2017 di bulan yang sama, yakni bulan Mei. Algoritma maximum-likelihood dipilih berdasarkan tingkat kemampuan membedakan objek basah dengan objek kering yang cukup baik.

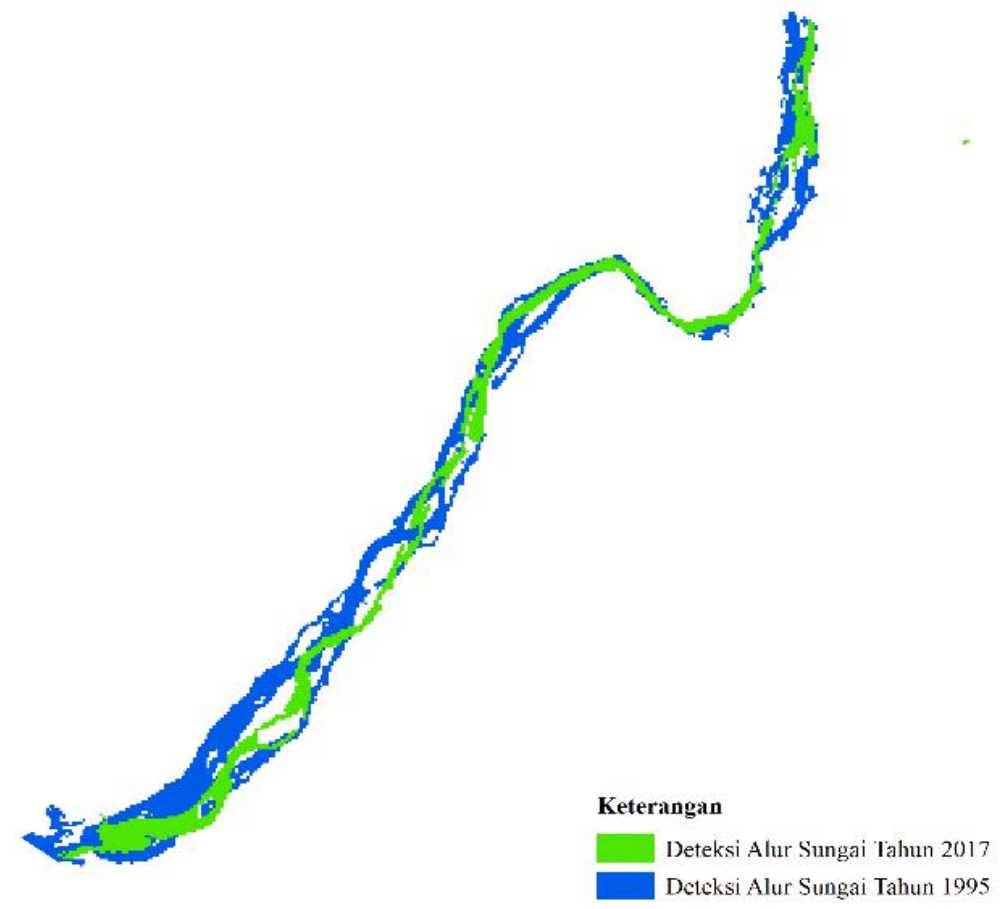

Gambar 9. Hasil proses klasifikasi berbasis spektral dari pola alur Sungai Progo tahun 1995-2017 
Hasil yang diperoleh dari ekstraksi pola alur Sungai Progo (Gambar 9) memperlihatkan pola alur sungai yang rumit dengan banyak gosong sungai pada kenampakan citra tahun 1995, sedangkan pada hasil ekstraksi citra tahun 2017 gosong sungai dan kelokan tidak terlihat dominan. Hasil ekstraksi dengan menggunakan metode klasifikasi digital (maximum likelihood) menghasilkan kenampakan pola alur secara cepat dan representatif, sehingga metode ini cocok digunakan untuk keperluan deteksi cepat terhadap perubahan pola alur sungai. Kelemahan deteksi sungai menggunakan metode klasifikasi digital adalah, pembacaan pola berdasarkan nilai piksel, sehingga terdapat beberapa kesalahan dalam klasifikasi karena nilai piksel memiliki kesamaan dengan objek lain di sekitar sungai.

\section{KESIMPULAN}

Penggunaan klasifikasi digital untuk mendeteksi perubahan pola alur sungai dari citra multispektral memungkinkan dilakukan dengan cepat dan efisien. Hasil yang diperoleh dari ekstraksi data penginderaan jauh menggunakan metode klasifikasi multispektral tersebut. Kelemahan dari penggunaan klasifikasi multispektral adalah terdapat beberapa daerah yang terklasifikasi tidak sesuai dengan keadaan di dunia nyata, sehingga pola alur sungai yang dihasilkan tidak dapat sehalus interpretasi manual.

\section{DAFTAR PUSTAKA}

Danoedoro, Projo. (2012). Pengantar Penginderaan Jauh Digital. Yogyakarta: Penerbit ANDI

Garde, R. (2006). River Morphology. New Delhi: New Age International (P) Limited Publisher.

Jayadi Rachmad, Legono Djoko. (2003). Pengelolaan Sub Daerah Aliran Sungai CiliwungCisadane dan Pengaruhnya Terhadap Pola Hidrograf Aliran di Bendung Katulampa dan Empang. Media Teknik XXV. $40-49$

Lillesand Thomas., M, Kiefer Ralph., W, Chipman W.,J. (2004) Remote Sensing and Image Interpretation Fifth Edition. New York : John Wiley \& Sons.

Mananoma Tyni, Sudjarwadi, Legono Djoko, Rahardjo Pamudi A. (2003). Fenomena Alamiah Erosi Dan Sedimentasi Sungai Progo Hilir. Jurnal dan Pengembangan Keairan No 1. 1-15.

Mananoma Tyni, Sudjarwadi, Legono Djoko, Rahardjo Pamudi A. (2006). Analisis Persamaan Transpor Sedimen Terhadap Fenomena Perubahan Morfologi Sungai Progo Tengah. Forum Teknik Sipil XVI. 221 - 232 
United State Geological Survey. (2016). Landsat 8 Data User Hand Book. United State: USGS

Viva. (2011). Belerang Merapi Ancam 200 Hektar Kolam Ikan. Diunduh dari: hwww.viva.co.id/berita/nasional/292726-belerang-merapi-ancam-200-hektar-kolam-ikan 